\title{
Editorial
}

\section{From Islamization of Knowledge to Islamization of Education}

Any Muslim intellectual who has a serious concern for the relatively deteriorating condition of the Muslim Ummah with respect to the Western World would be depressed and confused. However, the recent history of the Muslim World shows how many determined reformist movements played a positive role in changing the Muslim condition. But these movements met with partial or limited success.

It was in the late seventeenth, nineteenth, and early twentieth centuries, an ascendant Europe undermined and overran much of the Uthmani Dawlah (Ottoman Empire) and finally put an end to it, much to the shock and dismay of the Muslim World. The powerful European challenge and this drastic event elicited two contrasting responses from the Muslim elite and the masses. While many of them resorted to superficial imitation and initiated capricious copycat reform movements, some harnessed the rising awareness and the attendant spirit of resistance to launch more genuine efforts and reform movements. Understandably, these efforts were conflicting, emotional, and limited in their scope but they eventually helped Muslim societies to gain political independence in the post-World War II era. At the heart of these reforms and political liberation was the Muslim peoples' desire to realize their Islamic, national, and cultural aspirations along with the hope of enjoying a standard of living comparable to that of the West.

Unfortunately, these hopes were not achieved and the cultural reforms continued to be emotional, arbitrary, and patchwork (talfiq). The condition of the Muslim people continued to deteriorate and the gap between the Western world and the Muslim world continued to widen. The former continued to dominate and exploit that latter. All this proved that arbitrary, emotional, superficial, and limited patchwork reforms would not have a serious impact on the conditions of the Muslim people and will fail to realize their national or Islamic aspirations. 
The repeated lessons over three centuries have proved that there is no alternative to genuine reforms. Planning genuine reform is the first necessary step towards genuine development. Planning reforms should start with a deep understanding of the history of the people. Serious and sincere Muslim planning should first identify the underlying causes for the existing conditions, such as defects and shortcomings of the people's mentality and psychological structure, which precludes the Muslim peoples' ability to qualitatively and successfully face up to adversity. Muslim reforms should honestly address these fundamental problems and avoid advancing futile and superficial solutions. A strategy that deals only with the symptoms rather than the causes will only compound the problem and undermine all efforts. The planned reforms should reflect the spirit and the aspirations of the people and the Ummah and address real cultural and psychological problems. This is the only strategy that will motivate the Ummah to act and pursue effectively the desired reforms. It should be always remembered that nations and peoples do not have the same ideals, aspirations, and psychological structures. Effective ways and means to motivate different peoples should be in many different ways. To elevate peoples' conditions and achieve effective and everlasting reforms, cultural reform is the foundation for everything else. Cultural reform is a necessary condition for restructuring and rebuilding the moral, physical, and social life and system of peoples.

Cultural reform in Muslim societies has come a long way with prominent contributions from reformers like Muhammad Ibn Abdul Wahhab, Kwakibi, Afghani, Abduh, Tahtawi, Rida, al-Banna and Maududi. Finally, the initiative of Islamization of knowledge resolved some fundamental methodological issues and put the project of cultural reform on firm and genuine foundations to provide the right healthy and effective ideas and plans for a contemporary ummatic life system. The project of "Islamization of knowledge" has identified and distinguished Islamic sources of knowledge and established a comprehensive, analytical and systematic methodology, free of time-space problems in dealing with historical and contemporary challenges. Islamization of knowledge as a methodological foundation for cultural and social reform brings the Muslim world and Muslim intellectuals and political leaders to the step of second-stage of effective and comprehensive reforms to rebuild the Ummah's life and institutions. At this stage, the central question is where to begin rebuilding - in the economic, political, scientific, or military sectors? In order that the Ummah 
face the challenges confronting it, it is important that the Ummah and its leaders make the right choices.

It is clear that the heart of the Western challenge to the Ummah is scientific and technological, while the crux of the Muslim challenge to the West is spiritual, moral, and social. The West has no reliable, holistic, and authentic source to know and draw the boundaries of human freedom and social life. Only Islam has a revealed, authentic, and sound source of holistic comprehensive knowledge of the cause and nature of human life on earth. The Muslim dilemma lies in the fact the West and the rest of the world will not heed Islam's moral and spiritual message until Muslims respond adequately to their scientific and material challenge.

From the point of view of Islam, the Western challenge of science and technology poses no problems. In terms of material resources, Muslims have all the necessary resources to develop science, technology , and build their economies and industries. The problem lies in the fact that Muslims lack of an istikhlaf attitude and mentality to pursue creative scientific knowledge and development. They have given up the pursuit of knowledge and civilization (imran) as important Islamic lifelong duties. Therefore, if mentality and attitude is the underlying problem then reform of education is the answer. Education is the important means to change the psychology of children who will be the future members of society.

Rebuilding the life and the social system of the Ummah has manifolds. It includes political, social, economic, scientific, technology, and military aspects besides the field of education. But the rebuilding process has to go simultaneously on all these fronts. The important thing is that Muslims should coordinate their efforts and establish their priorities, where education comes at the top. The more Muslims give to the cause of education and development at this stage to create sound Muslim mentality and psychology, the more Muslims acquire higher capabilities in all other fields.

Muslims perhaps need the next forty years (a generation), very much like the Prophet Moses (pbuh), who dealt with people of distorted slave mentality, to raise and develop a new generation of strong, creative, courageous, and cooperative individuals and consolidated society. In ten years from now Muslim intellectuals should be able to transform the Muslim culture from one that is oppressive and individualistic to one that is generative and creative, a culture that will recapture the essence of prophetic style of tarbiyah, in which love, care and encouragement are the important means and methods. 
The immediate duty for Muslim intellectuals and educationists is to sift the Muslim culture and heritage from all wrong suppressive, and negative aspects of the culture. It is unwise to ignore the power of these shortcomings in our Muslim dominant culture. The oppressive and superstitious elements in the culture are seriously destroying the istikhlaf spirit of Islam and Muslim civilization. The cultural and educational reforms and efforts should no more stop at general and vague remarks and advices. Muslim educational reforms should produce educational literature, tarbiyah directions and school textbooks to help and guide parents and teachers in their successful efforts to raise the new psychologically and mentally healthy Muslim generations.

Muslim intellectuals and educationists, through Islamization of knowledge and the right Islamic methodology of thinking should sift successfully the Muslim culture and liberate, recapture, and reassert the Muslim identity. Thinkers and educationists should seriously start the next stage of the rebuilding of the Ummah's life and social system. The next natural stage after the Islamization of knowledge is the Islamization of the Muslim peoples and their minds. Islamization of the Muslim child and the coming Muslim generations is basically liberating them from a culture of fear and superstition to recapture and reestablish the Muslim spirit of tawheed and istikhlaf. It is the spirit of righteously and selflessly pursuing noble goals (islah), right knowledge (ma'rifah), and good and useful development (taskhir and imran).

Globalization left no false hopes of rebuilding behind artificial walls of protection. Global free trade and communication forced by the strong dominating materialist secular West on the Muslims and the rest of the world, left Muslims and their universal ummatic tawhidi message to nothing but their inner strength and the ability to revive and bring inner Islamic change and inner Islamic development. Aqidah (basic believes and values), tarbiyah and education are the only means for Muslims to renew their civilizational Islamic tawhidi moral contribution in the global village.

Muslim leaders and educators should abandon all old false hopes of isolation and protection. They have to get truly ready to compete and prove their worth. The tawhidi (unifying) universal message of Islam is the only universal message worthy and suitable for the man of the global village. Muslims should sift the Islamic universal message from all racial, nationalistic, and historical elements. Muslims should use suitable ways and means to communicate this great noble message to all kinds of human 
beings and to all parts of the world. Muslims should develop the right psychological discourses, communicate successfully the message to all kinds of people, being young or old, man or woman and Muslim or non-Muslim. Muslims should remember and make no mistake that the strong Quranic discourse was directed to adults to force them to carry their responsibilities. The Prophet (saw) educational and tarbiyah discourse to children and youth was very much different, it was a discourse of love, care, and development of proper character and attitude. Though he was a successful father and grandfather he never beat a child in his life.

The International Institute of Islamic Thought, the Association of Muslim Social Scientists and the American Journal of Islamic Social Sciences, welcome all kinds of help in the effort to Islamize education. The Institute, the Association and the Journal will provide all kinds of help in this regard. They will serve as an effective platform for the intellectual efforts to sift the Muslim culture and develop methods, principles, strategies, and texts to help parents and educators to raise the new Muslim generation. As of now it is only the sincere efforts, desires, and sacrifices of parents and devoted attention of teachers that are available ways to counter the wrong influences of media and other negative aspects of general education and popular culture.

Enlightened families and parents who shoulder and perform their responsibilities are the real safeguards and contemporary alternative to the Sinai of the Prophet Musa (as). It is not important in many ways what a child sees or hears. The most important thing is in which way the child understands what the child sees or hears. Families and parents can only legitimize any kind of effect of information and knowledge reaches the child. Effective parents and peers, whom parents should help select, work as colored glasses on the eyes and mind of the child. Parents' influence and their ways of tarbiyah would determine in many ways the quality of the child's character and mentality.

Together we should start this tremendous civilizational mission for the sake of the future generation of a peaceful global village.

AbdulHamid A. AbuSulayman Editor-in-Chief 